\title{
Ecological differentiation of members of the Culex pipiens complex, potential vectors of West Nile virus and Rift Valley fever virus in Algeria
}

Raouf Amara Korba ${ }^{1,2^{*}}$, Moufida Saoucen Alayat ${ }^{3}$, Lazhari Bouiba², Abdelkarim Boudrissa², Zihad Bouslama ${ }^{1}$, Slimane Boukraa ${ }^{4}$, Frederic Francis ${ }^{4}$, Anna-Bella Failloux ${ }^{5}$ and Saïd Chaouki Boubidi ${ }^{2}$

\begin{abstract}
Background: We investigated the ecological differentiation of two members of the Culex pipiens complex, Cx. $p$. pipiens form pipiens and CX. p. pipiens form molestus in three sites, El-Kala, M'Sila and Tinerkouk in Algeria. These two forms are the most widespread mosquito vectors in temperate regions exhibiting important behavioural and physiological differences. Nevertheless, this group of potential vectors has been poorly studied, particularly in North Africa.

Methods: Ten larval populations of $C x$. p. pipiens were sampled from various above- and underground habitats in three zones representing the three bioclimatic regions in Algeria. The reproduction characteristics were also investigated in the laboratory to define the rates of autogeny and stenogamy. Identification of Cx. p. pipiens members present in Algeria was achieved using a molecular analysis with the microsatellite CQ11 locus.

Results: We detected larvae of $C x$. p. pipiens in all areas suggesting that the species is a ubiquitous mosquito well adapted to various environments. To our knowledge, this study provides the first molecular evidence of the presence of the Cx. p. pipiens form molestus and hybrids (molestus/pipiens) in Algeria with a high proportion of molestus form (48.3\%) in comparison with hybrids (36.8 \%) and pipiens form (14.9\%).

Conclusions: Some unexpected correlations between the proportion of forms pipiens, molestus and hybrids, and mosquito biological characteristics were observed suggesting some epigenetic effects controlling CX. $p$. pipiens mating and reproduction. Consequences for pathogen transmission are discussed.
\end{abstract}

Keywords: Culex pipiens complex, Molestus, CQ11, Hybrid, Algeria, Autogeny, Stenogamy

\section{Background}

Culex pipiens pipiens is one of the most important mosquito species in terms of geographical distribution and ability to transmit pathogens [1]. In North Africa, $C x . p$. pipiens is a competent vector of several pathogens infecting animals and humans including West Nile virus (WNV) and Rift Valley fever virus (RVFV) [2-5]. In Algeria, $C x . p$. pipiens is the most widespread mosquito

\footnotetext{
*Correspondence: amarakorbaraouf@hotmail.com

'Laboratoire Ecologie des Systèmes Terrestres et Aquatiques, Département de Biologie, Faculté des Sciences, Université Badji Mokhtar, Annaba, Algérie ${ }^{2}$ Institut Pasteur d'Alger, Unité d'Entomologie Médicale, Service

d'Eco-épidémiologie parasitaire et génétique des populations, Alger, Algérie Full list of author information is available at the end of the article
}

species [6-9], and an efficient vector of WNV and to a lesser extent, of RVFV in experimental conditions [5].

The first isolation of WNV in Algeria was in Djanet, southeast of the country in 1968 [10]. The virus was isolated from a pool of 215 mosquitoes belonging to the genus Culex. In 1994, the virus appeared again causing an outbreak with a total of 50 human cases including eight deaths in Tinerkouk (Adrar Department, southeast Algeria) [11]. From neighbouring countries, other human and equine cases were reported in Tunisia in 1997, while only equine cases were detected in 1996 in Morocco $[12,13]$. In the following years, other human cases were reported: in Morocco in 2003 [14] and in Tunisia between 
2003 and $2012[15,16]$ suggesting that WNV is still circulating within the region. In western Africa, a major RVF outbreak occurred, close to Algeria, in Mauritania and in Senegal in 1987 and resulted in 220 human deaths [17]. Moreover, a recent study identified the Maghreb region as high-risk countries for RVF emergence [18].

Culex $p$. pipiens exists in two forms or biotypes that exhibit substantial differences in both behavioural and physiologic characteristics but are morphologically indistinguishable [19]. In Europe, $C x$. p. pipiens form molestus is considered as stenogamous (mates in confined spaces), autogenous (able to lay its first batch of eggs without a blood meal), prefers underground water bodies with high organic contents and does not diapause. In contrast, $C x . p$. pipiens form pipiens is considered as eurygamous (mates while swarming in open areas), anautogenous (requires a blood meal to lay eggs), overwinters (enters reproductive diapause) and colonizes a wide variety of aboveground breeding sites [20]. Several studies suggest that both forms have different trophic preferences: form pipiens biting mainly birds and form molestus feeding on mammals including humans, whereas hybrids exhibit an opportunistic behaviour and can readily feed on both hosts [21]. However, several studies also mention a potential local variation in host selection depending on host availability [22]; these feeding behaviours are thought to influence the transmission of avian and mammalian pathogens [21].

For a better implementation of vector control measures, molecular identification, biological and ecological characterisation of the $C x$. p. pipiens forms present in Algeria is of prime importance. In this study, we used the microsatellite locus CQ11 to analyse samples of $C x$. $p$. pipiens collected in both aboveground and underground habitats in three bioclimatic regions of the country (humid, sub-arid and arid). Reproductive strategies of $C x$. pipiens complex forms were compared for a better understanding of their adaptability according to their environment.

\section{Methods}

\section{Study area}

Algeria is divided into three major bioclimatic regions based on the classification of Emberger [23]: humid, sub-arid and arid. Three sites were selected: El-Kala in the humid region El-Tarf department; $\left(36^{\circ} 53^{\prime} \mathrm{N}, 8^{\circ} 26^{\prime} \mathrm{E}\right)$ with pluviometry: $900-1200 \mathrm{~mm} /$ year, M'Sila department $\left(5^{\circ} 7^{\prime} \mathrm{N}, 4^{\circ} 33^{\prime} \mathrm{E}\right)$ and pluviometry: $300-600 \mathrm{~mm} /$ year, and Tinerkouk in the arid desert region at Adrar department; $\left(29^{\circ} 42^{\prime} \mathrm{N}, 0^{\circ} 43^{\prime} \mathrm{E}\right)$ with pluviometry: $<100 \mathrm{~mm} /$ year (Fig. 1). The area of El-Kala was selected partly because of the high diversity of potential breeding sites for $C x . p$. pipiens and their proximity to relatively dense human populations and other hosts including migratory birds, suggesting that it could be a hotspot for WNV circulation. The department of M'Sila is characterized by an intermediate climate between the north and the south of the country where the inhabitants complain regularly about an important nuisance caused by mosquitoes. The area of Tinerkouk was selected owing to its arid climate and because this city has experienced a WNV outbreak in 1994. In each bioclimatic region, different habitats were chosen: urban (centre of the city), sub-urban (outskirts of the city) and rural (outside the city). In each habitat, aboveground and underground breeding sites were examined if available. Six categories of larval habitat were then selected (e.g. Fig. 2).

\section{Mosquito collections}

A total of 10 sites were classified according to the habitat (urban, suburban or rural) and the type of breeding site (aboveground or underground) (Table 1). Fourth instar larvae were sampled from May to October 2010 using the dipping method [24] with ten dips in different places of the breeding site. Larval density was expressed as numbers of larvae per litre and estimated according to a range of five classes: class 1 for larval density $=0$, class 2 for larval density $=10(1-10)$, class 3 for larval density $=50(11-50)$, class 4 for larval density $=100(51-$ $100)$, class 5 for larval density $=500(>100)$. Ecological data characterizing each breeding site were recorded: the presence of vegetation (Additional file 1: Table S1), temperature, $\mathrm{pH}$, salinity and percentage of $\mathrm{O}_{2}$ (Table 1 ). The water of each breeding site was analysed for BOD5 (Biological Oxygen Demand) to estimate the concentration of organic matter and evaluate the correlation with larval densities.

\section{Reproduction characteristics}

Larvae collected from each breeding site were sorted and reared in an insectarium at $26 \pm 2{ }^{\circ} \mathrm{C}$ and relative humidity of $70 \% \pm 10 \%$; they were placed in plastic pans $(18 \times 25 \times 5 \mathrm{~cm})$ at a concentration of 200 larvae per litre and were fed with commercial cat food (Purina ONE ${ }^{\circ}$ ). Pupae were isolated individually in glass tubes with $10 \mathrm{ml}$ of distilled water until emergence of adults. Fourty pairwise males and females were constituted for each breeding site and maintained for 3-5 days under a $12 \mathrm{~h}$ : $12 \mathrm{~h} \mathrm{LD}$ photoperiod and a relative humidity of $60-80 \%$ in $500 \mathrm{ml}$ cardboard cups covered with a mesh screen and a piece of cotton soaked with $10 \%$ sugar solution was provided as nutrient. Then, half of females (20) were removed using a mouth aspirator and placed in a cage $(25 \times 25 \times 25 \mathrm{~cm})$ covered with a mesh screen and males were removed and stored at $-20{ }^{\circ} \mathrm{C}$ for molecular identification. Those females were deprived of sugar solution for $24 \mathrm{~h}$ before being exposed to a quail (Coturnix japonica) maintained in a small metal cage $(20 \times 10 \times 10 \mathrm{~cm})$. The quail was provided for one hour/day during 3 consecutive days until most of mosquitoes had successfully obtained a blood 


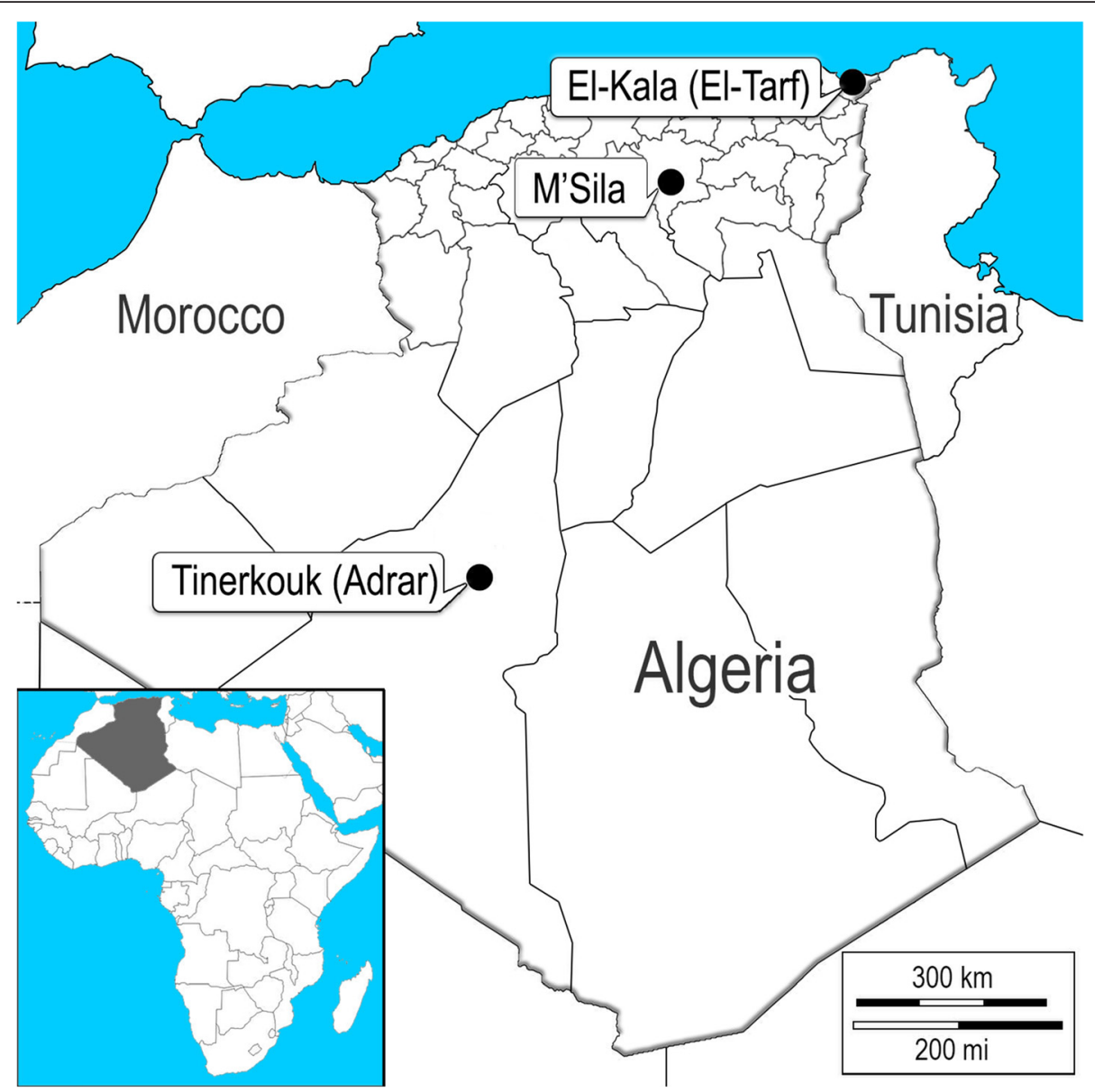

Fig. 1 Localization of Cx. p. pipiens samples collected in 2010 in Algeria

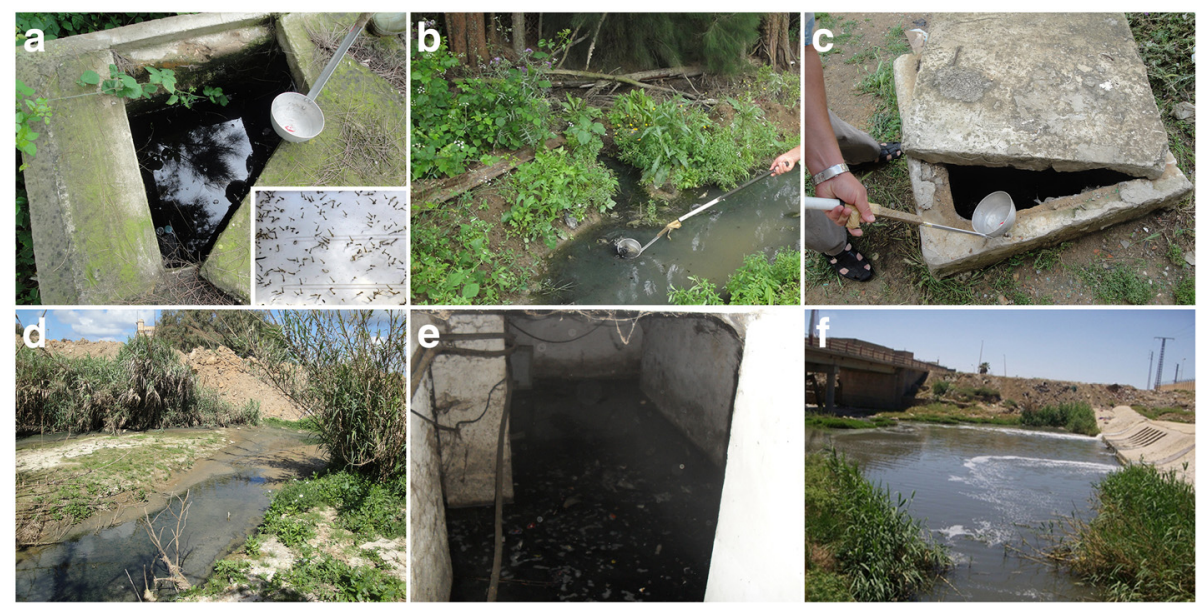

Fig. 2 Different types of breeding sites where CX. p. pipiens populations were sampled. a Underground-rural El-Kala. b Aboveground-rural El-Kala. c Underground sub-urban El-Kala. d Aboveground urban El-Kala. e Underground urban El-Kala. f Aboveground sub-urban M'Sila 
Table 1 Chemical and physical properties of the larval habitats of CX. p. pipiens

\begin{tabular}{|c|c|c|c|c|c|c|c|c|}
\hline Site & Habitat & Breeding sites & Mean density of larvae & $\mathrm{pH}$ & Temperature $\left({ }^{\circ} \mathrm{C}\right)$ & Salinity $(\mathrm{g} / \mathrm{l})$ & $\mathrm{O}^{2}(\%)$ & BOD5 (mg/l) \\
\hline \multirow[t]{6}{*}{ El-Kala } & \multirow[t]{2}{*}{ Urban } & Underground & 66 & 7.3 & 21.1 & 0.5 & 1 & 190 \\
\hline & & Aboveground & 255 & 7.8 & 21.4 & 0.4 & 1 & 6 \\
\hline & \multirow[t]{2}{*}{ Sub-urban } & Underground & 340 & 7.8 & 19.2 & 0.7 & 0 & 3 \\
\hline & & Aboveground & 38 & 8 & 19.1 & 0.6 & 0 & 28 \\
\hline & \multirow[t]{2}{*}{ Rural } & Underground & 160 & 8.3 & 20.2 & 0.9 & 1 & 6 \\
\hline & & Aboveground & 380 & 7.9 & 26.4 & 0.8 & 0 & 32 \\
\hline \multirow[t]{3}{*}{ M'Sila } & Urban & Underground & 27 & 7.9 & 19.7 & 1.1 & 1 & 7 \\
\hline & Sub-urban & Aboveground & 165 & 8.1 & 20.3 & 1.8 & 0 & 12 \\
\hline & Rural & Aboveground & 165 & 8.1 & 24.0 & 1.7 & 1 & 32 \\
\hline Tinerkouk & Urban & Underground & 13 & 7.4 & 28.6 & 0.8 & 0.5 & 384 \\
\hline
\end{tabular}

BOD5, Biological Oxygen Demand

meal. Engorged females were individually maintained in cardboard cups and provided with sugar solution. The other half of females (20) were only supplied with a sugar solution and a cup of water was provided for egg laying. Several characteristics were then evaluated: autogeny/anautogeny, stenogamy/eurygamy, fecundity, fertility, and molecular identification.

\section{Autogeny/anautogeny}

Females able to lay eggs without any blood meal were qualified as autogenous (AU) and those which required a blood-meal as anautogenous (AN). The number of eggs laid by each female was counted. Number of specimens tested in each population $(n=20)$.

\section{Stenogamy/eurygamy}

Females able to mate in cups and capable of laying fertile eggs were considered as stenogamous. In contrast, females unable to be inseminated in confined spaces (laid sterile eggs) were qualified as being eurygamous. Number of specimens tested in each population $(n=40)$.

\section{Fecundity and fertility}

The fecundity rate corresponded to the number of eggs laid per female. Fertility rate was estimated by the proportion of larvae hatched from laid eggs. These proportions were compared between females which received a blood meal and those that received only sugar solution. Number of specimens tested in each population $(n=40)$.

\section{Molecular identification}

Culex $p$. pipiens mosquito populations belonging to the 10 studied sites were classified according to their phenotypes (autogenous/anautogenous, stenogamous/eurygamous) and then we performed a correlation between obtained phenotypes and the genotypes of those populations assessed by multiplex PCR assay described in Bahnck \& Fonseca (2006) [25]. A leg was placed directly into the reaction mixture containing primers amplifying the microsatellite CQ11 locus used to distinguish between the two forms of $C x$. pipiens complex: pipiens and molestus (Additional file 2: Figure S2). The primers used were: pipCQ11R 5'CAT GTT GAG CTT CGG TGA A-3' and molCQ11R 5'-CCC TCC AGT AAG GTA TCA AC-3'. The forward primer CQ11F2 5' GAT CCT AGC AAG CGA GAA C-3'. The DNA fragment size amplified varied between pipiens and molestus allowing us to distinguish the two forms in a single PCR reaction. Polymerase chain reaction (PCR) $>$ products were run on a $2 \%$ agarose gel. The pipiens and molestus forms presented PCR products of $180 \mathrm{bp}$ and $250 \mathrm{bp}$, respectively. Hybrids exhibited both amplicons (180 bp/250 bp).

\section{Data analysis}

Chi-square test was used for comparisons of rates (autogeny, stenogamy and the molecular forms of $C x$. p. pipiens), Kruskal-Wallis $\mathrm{H}$ test to study the spatial variation of rates (autogeny, stenogamy) and Mann-Whitney test to evaluate the influence of blood meal on fecundity and fertility rates. All statistical tests were conducted using the $\mathrm{IBM}^{\circ} \mathrm{SPSS}^{\circ}$ Statistics for windows v.21 (IBM Corp. Armonk, NY). $P$-values $>0.05$ were considered non-significant.

\section{Results}

All habitats investigated were colonized by $C x$. $p$. pipiens.

Culex $p$. pipiens is sensitive to high levels of organic matter The chemical and physical properties of breeding sites were analysed as factors that could influence larval development (Additional file 3: Figure S1). pH, temperature, salinity, and dissolved oxygen exhibited comparable values without any relation with larval densities (Table 1). The density of larvae increased when the BOD5 decreased. The highest densities of larvae were found in the three breeding sites in the city of El-Kala corresponding to low levels of BOD5 (Table 1). The highest level of BOD5 was recorded 
in an urban underground breeding site in Tinerkouk, which was associated with a low larval density and the highest temperature of breeding site (Table 1).

\section{Autogeny/anautogeny}

To define whether autogenous mosquitoes were more prevalent in underground sites, we examined mosquitoes collected in El-Kala and found that autogenous mosquitoes were mostly a minority in breeding sites without any clear-cut relation with the habitat (above- or underground) (Fig. 3a). When considering a given habitat (urban, sub-urban or rural), the highest proportion of autogenous mosquitoes were found in underground breeding sites [Chi-square test: urban $\left(\chi^{2}=2.054, d f=1, P=0.151\right)$, suburban $\left(\chi^{2}=8.286, d f=1, P=0.004\right)$ and rural $\left(\chi^{2}=4.444\right.$, $d f=1, P=0.035)]$. When only analysing underground breeding sites in urban habitats of the three sites, El-Kala, M'Sila and Tinerkouk, the proportion of autogenous mosquitoes increased from El-Kala to Tinerkouk (Fig. 3b) (Kruskal-Wallis $\mathrm{H}$ test: $\chi^{2}=26.761, d f=2, P<0.0001$ ).

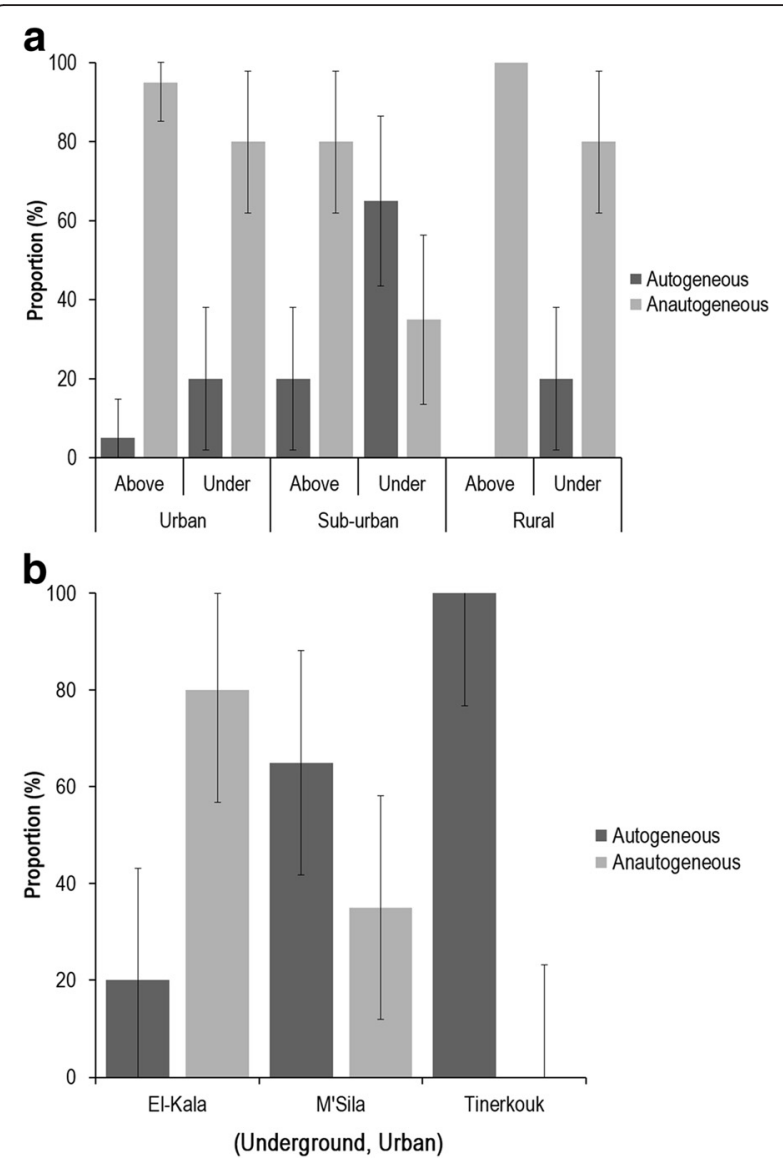

Fig. 3 Proportions of autogenous/anautogenous CX. p. pipiens collected in El-Kala (a) and in underground breeding sites in urban environments (b). Error bars indicate the $95 \%$ confidence interval

\section{Stenogamy/Eurygamy}

Eurygamous mosquitoes predominated in El-Kala (Fig. 4a); Chi-square test: urban $\left(\chi^{2}=8.286, \quad d f=1, \quad P=0.004\right)$, sub-urban $\left(\chi^{2}=36.450, d f=1, P<0.0001\right)$, rural $\left(\chi^{2}=\right.$ 54.450, $d f=1, P<0.0001$ ) and in M'Sila (Fig. 4b) urban $\left(\chi^{2}=1.600, d f=1, P=0.206\right)$, rural $\left(\chi^{2}=14.400, d f=1\right.$, $P<0.0001)$ and sub-urban $\left(\chi^{2}=3.600, d f=1, P=0.058\right)$ whatever the breeding site (above- or underground). Conversely, stenogamous mosquitoes predominated in the underground urban site of Tinerkouk (Fig. 4c) (Chi-square test: $\left.\chi^{2}=12.100, d f=1, P=0.001\right)$. When considering the given habitat (urban, sub-urban or rural), the highest proportion of stenogamous mosquitoes were found in underground breeding sites in El-Kala, especially in rural habitats (Chi-square test: $\chi^{2}=7.671, d f=1, P=$ 0.006 ), but not in M'Sila. When only considering underground urban sites, the proportion of stenogamous mosquitoes increased significantly from El-Kala to Tinerkouk (Fig. 4d) with a tendency similar to the proportion of autogenous females (Fig. 3b) (Kruskal-Wallis H test: $\left.\chi^{2}=25.168, d f=2, P<0.0001\right)$.

\section{Fecundity and fertility}

To examine whether the mosquito status autogenous/ anautogenous affects the number of eggs laid, we estimated the fecundity corresponding to the number of laid eggs per female and the fertility referring to the hatching success of laid eggs. Blood feeding increased the number of eggs laid by mosquitoes collected in El-Kala (Fig. 5a; Mann-Whitney test: $U=218, P=0.028$ ), M'Sila (Fig. $5 \mathrm{~b}$; Mann-Whitney test: $U=19.5, P<0.0001)$ and Tinerkouk (Fig. 5c; Mann-Whitney test: $U=23, P<0.0001$ ). When only considering blood-fed mosquitoes from underground urban sites, the fecundity increased from El-Kala to Tinerkouk (Kruskal-Wallis H test: $\chi^{2}=8.062, d f=2, P=0.018$ ), whereas it remained constant for unfed mosquitoes (Fig. 5d). When analysing fertility, blood feeding did not significantly affect the hatching success of eggs collected in El-Kala (Fig. 6a), M'Sila (Fig. 6b) and Tinerkouk (Fig. 6c). When only considering mosquitoes from underground urban sites, the fertility slightly increased from $10 \%$ for El-Kala to $20 \%$ for Tinerkouk whether mosquitoes were fed or unfed (Fig. 6d).

\section{Molecular identification}

A total of 87 adults were characterized by PCR and frequencies of different forms are represented in Table 2 . Overall, $14.9 \%$ of the adults tested belonged to the pipiens form, $48.3 \%$ to the molestus form and the remaining $36.8 \%$ corresponded to hybrids (Additional file 2: Figure S2). Most breeding sites examined contained the three genetic forms of $C x . p$. pipiens with a predominance of the molestus form. The pipiens form showed a preference for aboveground habitats (Chi-square 

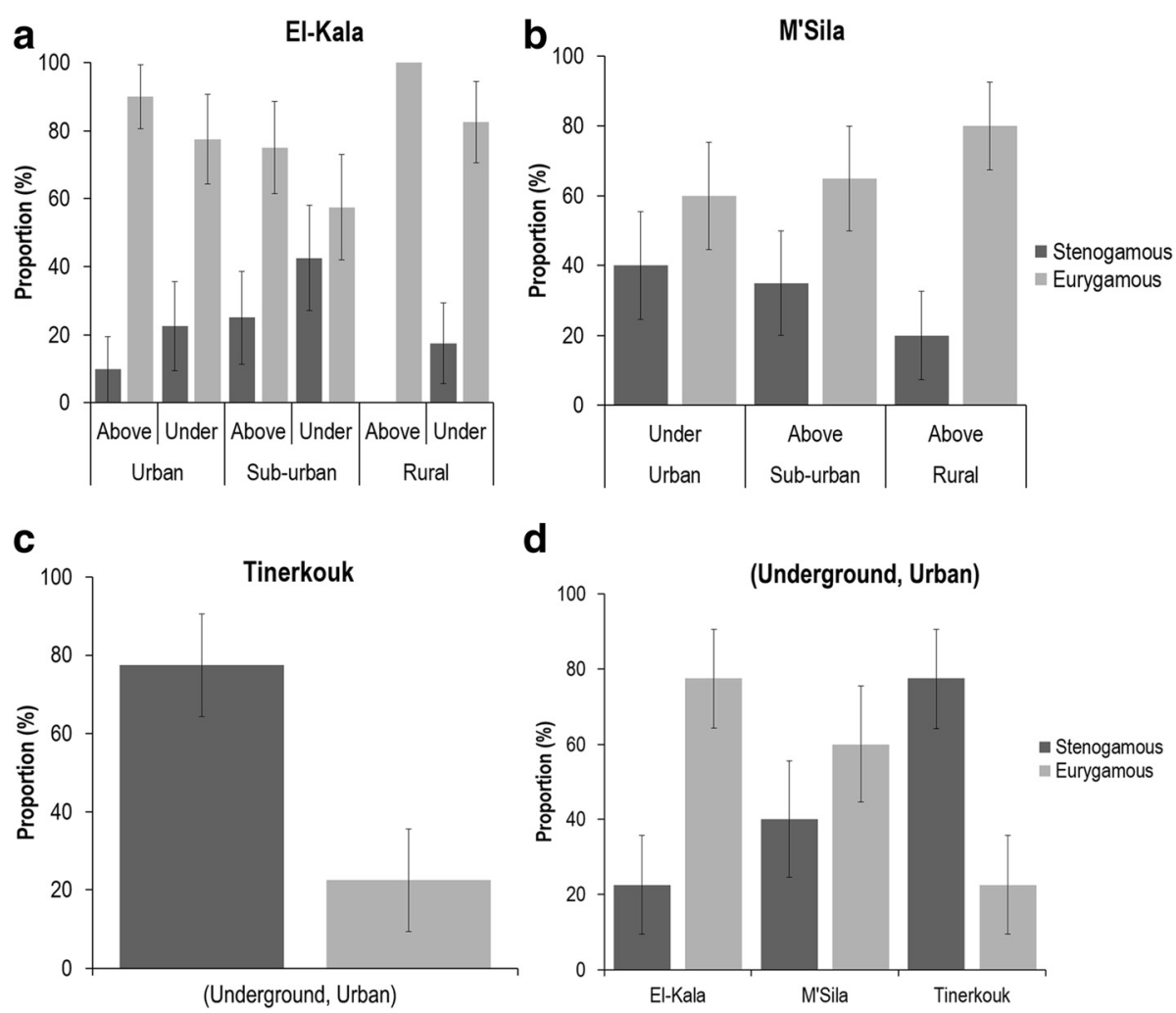

Fig. 4 Proportions of stenogamous / eurygamous CX. p. pipiens collected in El-Kala (a), M'Sila (b), Tinerkouk (c), and in underground breeding sites in urban environments (d). Error bars indicate the $95 \%$ confidence interval
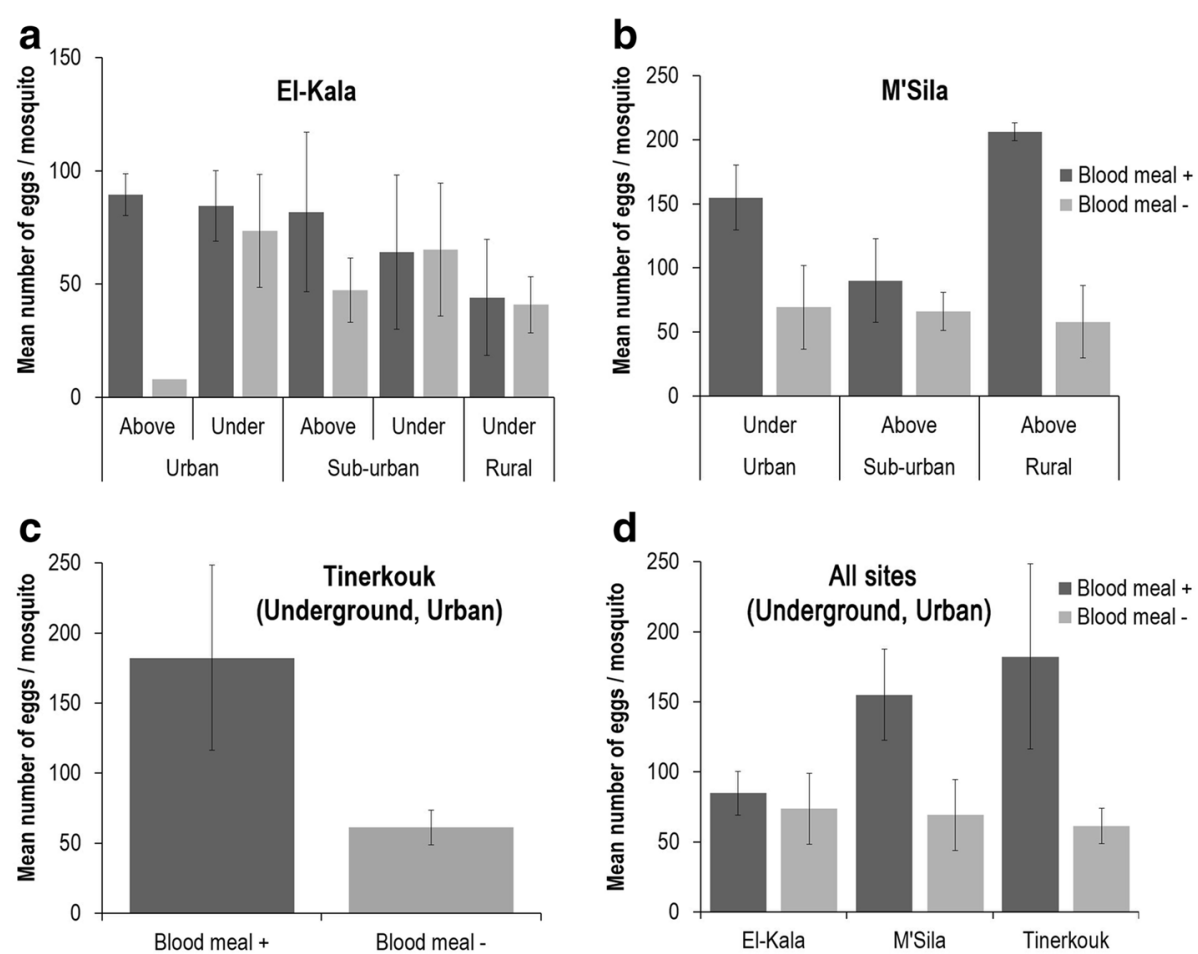

Fig. 5 Fecundity expressed by the mean number of eggs laid by mosquitoes collected in El-Kala (a), M'Sila (b), Tinerkouk (c), and in underground breeding sites in urban environments (d). Error bars indicate the $95 \%$ confidence interval 

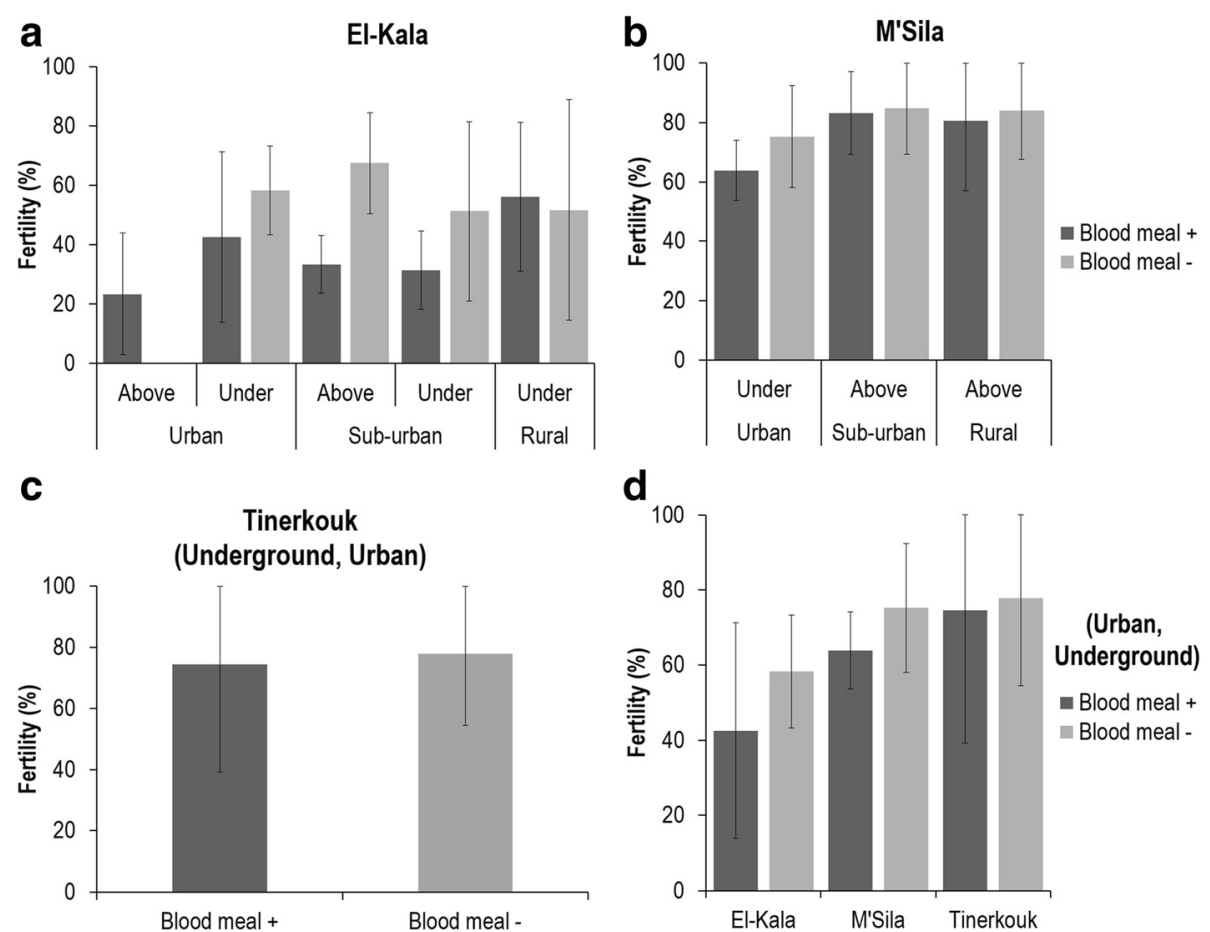

Fig. 6 Fertility corresponding to the mean number of eggs hatched from eggs laid by mosquitoes collected in El-Kala (a), M'Sila (b), Tinerkouk (c), and in underground breeding sites in urban environments (d). Error bars indicate the $95 \%$ confidence interval

test: $\chi^{2}=6.100, d f=1, P=0.013$ ), while the molestus form and hybrids did not present any preference for aboveground or underground habitats [Chi-square test: molestus $\left(\chi^{2}=0.857, d f=1, P=0.355\right)$, hybrids $\left(\chi^{2}=0.50, d f=1\right.$, $P=0.48)]$. As expected, pipiens $f$. were mainly anautogenous/eurygamous, but molestus f. were at $78.6 \%$ autogenous/stenogamous and hybrids presented several reproductive characteristics (Table 3 ). Thereby, only $6(18.7 \%)$ hybrids issued from Tinerkouk have

Table 2 Frequencies of different forms of the Culex pipiens complex in Algeria

\begin{tabular}{|c|c|c|c|c|c|}
\hline \multirow[t]{2}{*}{ Site } & \multirow[t]{2}{*}{ Habitat } & \multirow{2}{*}{$\begin{array}{l}\text { Breeding } \\
\text { sites }\end{array}$} & \multicolumn{3}{|c|}{ Frequency (\%) } \\
\hline & & & pipiens & molestus & hybrids \\
\hline \multirow[t]{6}{*}{ El-Kala } & Urban & Underground & 0 & $4(44.4)$ & $5(55.5)$ \\
\hline & & Aboveground & $4(40)$ & $3(30)$ & $3(30)$ \\
\hline & Sub-urban & Underground & 0 & $7(100)$ & 0 \\
\hline & & Aboveground & $1(12.5)$ & $2(25)$ & $5(62.5)$ \\
\hline & Rural & Underground & $1(10)$ & $8(80)$ & $1(10)$ \\
\hline & & Aboveground & $1(14.3)$ & $4(57.1)$ & $2(28.6)$ \\
\hline \multirow[t]{3}{*}{ M'Sila } & Urban & Underground & 0 & $2(25)$ & $6(75)$ \\
\hline & Sub-urban & Aboveground & $1(16.7)$ & $5(83,3)$ & 0 \\
\hline & Rural & Aboveground & $4(33.3)$ & $4(33.3)$ & $4(33.3)$ \\
\hline Tinerkouk & Urban & Underground & $1(10)$ & $3(30)$ & $6(60)$ \\
\hline Total & & & 13 (14.9) & $42(48.3)$ & $32(36.8)$ \\
\hline
\end{tabular}

expressed an autogeneous behaviour while $81.3 \%$ were anautogenous from other sites (Table 3).

\section{Discussion}

This study corroborates that the human-biting Culex pipiens pipiens is a ubiquitous mosquito well adapted to a wide range of environments through the expression of a biological plasticity for mating and reproduction. Intriguingly, whatever the habitat (urban, sub-urban or rural) and the type of breeding site (above- and underground), the proportion of autogenous and stenogamous mosquitoes increased from El-Kala in the humid bioclimatic region to Tinerkouk in the arid desert region and consequently, fecundity and fertility also increased. Molecular identification underlines the predominance of $C x . p$. pipiens form molestus and hybrids which may increase the WNV transmission [26]. Fonseca et al. [21] showed using molecular markers, that in North America $40 \%$ of Cx. pipiens females have genetical characteristics of hybrids between the two European biotypes, molestus and typical pipiens (s.s.): they feed readily on both birds and humans thereby serving as efficient bridge vectors of WNV.

The growth and development of mosquitoes are largely determined by the environmental conditions experienced during the immature stages [27]. The quality and quantity of the larval diet shapes adult phenotypes, some of which may be important determinants of vectorial capacity [28]. The chemical and physical analysis 
Table 3 Frequencies (\%) of different forms of the Culex pipiens complex in Algeria related to their phenotype status

\begin{tabular}{|c|c|c|c|c|c|c|c|c|c|c|}
\hline \multicolumn{6}{|c|}{ Underground sites } & \multicolumn{5}{|c|}{ Aboveground sites } \\
\hline Form & AU/ST & AU/EU & AN/ST & AN/EU & TOTAL & $\mathrm{AU} / \mathrm{ST}$ & AU/EU & AN/ST & AN/EU & TOTAL \\
\hline pipiens & 0 & 0 & 0 & $\begin{array}{l}100 \\
(n=2)\end{array}$ & 2 & 0 & 0 & $\begin{array}{l}0.091 \\
(n=1)\end{array}$ & $\begin{array}{l}90.9 \\
(n=10)\end{array}$ & 11 \\
\hline molestus & $\begin{array}{l}62.5 \\
(n=15)\end{array}$ & $\begin{array}{l}4.2 \\
(n=1)\end{array}$ & $\begin{array}{l}33.3 \\
(n=8)\end{array}$ & 0 & 24 & $\begin{array}{l}77.8 \\
(n=14)\end{array}$ & $\begin{array}{l}16.7 \\
(n=3)\end{array}$ & 0 & $\begin{array}{l}5.5 \\
(n=1)\end{array}$ & 18 \\
\hline hybrid & $\begin{array}{l}22.2 \\
(n=6)\end{array}$ & 0 & $\begin{array}{l}16.7 \\
(n=3)\end{array}$ & $\begin{array}{l}61.1 \\
(n=11)\end{array}$ & 18 & 0 & 0 & $\begin{array}{l}35.7 \\
(n=5)\end{array}$ & $\begin{array}{l}64.3 \\
(n=9)\end{array}$ & 14 \\
\hline
\end{tabular}

of 10 larval breeding sites showed that $C x . p$. pipiens larvae develop at high densities in water moderately charged in organic matter. A highly polluted breeding site can inhibit larval development. The adaptive potential of $C x$. pipiens (s.l.) is remarkable; larvae are able to breed in a great variety of habitats and adults to survive in different biotopes. The two forms, pipiens and molestus, presented specific biological requirements, which led them to colonize distinct biotopes. The anautogenous pipiens form needs to blood feed on accessible hosts imposing them to breed in aboveground sites (e.g. open ditches, rain barrels, etc.) whereas the autogenous molestus form colonizes underground sites (e.g. subways, covered wells, etc.) $[29,30]$. High organic contents is mainly associated with autogenous mosquitoes [31, 32].

The molestus form can be distinguished from the pipiens form by consistent differences in the expression of facultative autogeny [32] and stenogamy [33-36]. Thus, underground sites were expected to host a higher proportion of autogenous and stenogamous females. We showed that a high proportion of anautogenous and eurygamous mosquitoes can be found in some underground sites, presumably related to the occurrence of a high proportion of hybrids or a mixed population between molestus and pipiens resulting from overflow of underground to aboveground breeding sites. Moreover, we showed that pipiens and molestus forms were mainly anautogenous/eurygamous ( 100\%) and autogenous/ stenogamous (78.6\%), respectively. However, we underlined that hybrids can express several phenotypes. In the same line, we observed that only six (18.7\%) of all hybrids issued from Tinerkouk have expressed an autogeneous behaviour while $81.3 \%$ were anautogenous from the other sites. Spielman [32] demonstrated that in North America, hybrids resulting from the hybridization between autogenous and anautogenous mosquitoes can produce fertile eggs autogenously, sterile eggs and eggs with an anautogenous phenotype. We also found high densities of autogenous mosquitoes corresponding to molestus form colonizing preferentially aboveground sites; this result contrasts with observations in the Palaearctic region [37]. We also found that the proportion of hybrids (36.8 \%) is higher than in Kothera et al.'s paper
[38] where they found that the rate of hybrids from United States populations of $C x . p$. pipiens ranged from 4 to $15 \%$. One explanation would be that in the studied areas, above and underground breeding sites are too close to each other, which may help frequent contacts and then mating between the two forms. Intriguingly, a lot of molestus form was detected in aboveground sites, which is in agreement with the observations of Nelms et al. [26].

We found a positive correlation between blood meal and egg production. Anautogenous mosquitoes are expected to be more fecund and to produce more than 400 eggs after feeding on a chicken $[39,40]$. We showed that the blood meal increases the number of eggs produced ( 120 eggs/mosquito) compared to mosquitoes fed on sugar only ( 62 eggs/mosquito), as expected [29]. Blood feeding conditions egg production [41], adult longevity [42], oviposition [43], egg size [44] and egg-clutch size [45]. Nevertheless, blood meal does not influence fertility.

We found that the geographical distribution of the two forms pipiens and molestus overlaps in the same habitats in Algeria. Sympatric distribution of both forms has been already described in Europe [46-49], USA [21], Morocco [50] and Tunisia [51]. Hybrids may play the role of bridge vectors for pathogen transmission between animals and humans as this has been demonstrated in the USA for WNV [21, 52]. Hybrids were also detected in southern [47] and northern Europe [53]. Both pipiens and molestus forms are efficient vectors of West Nile and other arboviruses [54-56]. Moreover, in a previous study we showed that $C x . p$. pipiens populations collected in Algeria were highly susceptible to infection and readily able to transmit WNV and to a lesser extent, RVFV [5].

In an anticipated result, the expression of some biological characteristics such as autogeny and stenogamy differs from northern breeding sites to southern ones, from the humid bioclimatic region in the north to the arid desert region in the south. The underground site in Tinerkouk was exposed to relatively high concentrations of dissolved organic matter and also to high temperatures compared to a similar site in El-Kala (see Table 1). Tinerkouk site also hosted $C x$. $p$. pipiens expressing the highest levels of autogeny and stenogamy attributed 
mostly to hybrids and to a lesser extent, to molestus form as it was expected (see Table 2). It is well documented that nutritional factors [57] as well as exposure to high temperatures [58] can cause epigenetic alterations resulting in an increase of global DNA methylation. Changes in DNA methylation whose level varied inversely with gene transcription seemed to play a role in facilitating plasticity in response to environmental stress leading to micro-evolutionary changes in populations [59]. A clear example of how environment plays an important role in shaping the epigenome is represented by monozygotic twins, who are epigenetically indistinguishable early in life but with age exhibit substantial differences in epigenetic markers [60]. The effect of environment on epigenome changes is obvious even in flowering plants where vernalization requires methylation of specific histone arginine and lysine residues [61, 62], revealing a link between temperature and chromatin state. It would be tempting to speculate that autogeny and stenogamy are induced phenotypes that can be transmitted to the progeny with consequences on their vectorial potential.

\section{Conclusions}

This study represents the first molecular evidence of $C x$. pipiens complex forms (pipiens, molestus and hybrids) in Algeria. Our results show the simultaneous occurrence of the three biotypes, often in sympatry, both in above- and underground environments. Our findings also indicate that molestus and hybrid forms include populations that have an unusual mixture of phenotypes and differ from northern breeding sites to southern ones, indicating a possible implication of epigenetic phenomenon. These particular biological traits seem to be an adaptive process to the tough conditions in the Saharan area. Our data demonstrate a great plasticity of this complex of mosquitoes to a wide range of ecological conditions and provide valuable information for implementation of controlling methods.

\section{Additional files}

Additional file 1: Table S1. Major plant groups found around the breeding sites of Culex pipiens (s.l.) (DOCX $15 \mathrm{~kb}$ )

Additional file 2: Figure S2. PCR amplification of the flanking region of the CQ11 microsatellite of Culex pipiens collected in an aboveground rural site in M'Sila (Algeria). One leg was used as DNA source directly in the mix. PCR products were run on a $2 \%$ agarose gel and individuals were scored according to the band size. (DOCX $146 \mathrm{~kb}$ )

Additional file 3: Figure S1. Relation between BOC5 (Biological oxygen consumption) and mean density of Culex pipiens (s.l.) larvae. (DOCX 22 kb)

\section{Acknowledgments}

We thank partners of the ACIP project: Ali Bouattour, Ghazi Krida, and Mhammed Sarih. We also thank François Rougeon and Michael J. Turell for their support and critical comments on this work.

\section{Funding}

This work was funded by the Institut Pasteur (ACIP grant A-08-2009) and the French Government's Investissement d'Avenir program, Laboratoire d'Excellence "Integrative Biology of Emerging Infectious Diseases" (grant $n^{\circ}$ ANR-10-LABX-62-IBEID). AKR was supported by PhD fellowship «Biodiversity, Evolution and Ecology of Health » from the Algerian Ministry of Higher Education and Scientific Research.

\section{Availability of data and material}

The datasets supporting the conclusions of this article are included within the article and its additional files.

\section{Authors' contributions}

RAK, MSA, AB, SB, SCB performed field studies. RAK, MSA, SCB performed mosquito rearing. SCB identified mosquitoes. RAK, MSA, SCB performed bioecological study. MSA, LB, SB, FF, SCB performed mosquito genotyping (PCR, Sequencing). RAK, ABF performed statistical analyses. RAK, SCB, ABF, ZB wrote the manuscript. All authors read and approved the final version of the manuscript.

\section{Competing interests}

The authors declare that they have no competing interests.

\section{Consent for publication}

Not applicable.

\section{Ethics approval and consent to participate}

The Algerian Institute Pasteur animal facility has received accreditation from the Algerian Ministry of Agriculture to perform experiments on live animals in compliance with the Algerian and International regulations on care and protection of laboratory animals. This study was approved by the Institutional Animal Care and Use Committee (IACUC) at the Institute Pasteur of Algeria. No specific permits were required for the described field studies in locations which are not protected in any way and did not involve endangered or protected species.

\section{Author details}

${ }^{1}$ Laboratoire Ecologie des Systèmes Terrestres et Aquatiques, Département de Biologie, Faculté des Sciences, Université Badji Mokhtar, Annaba, Algérie. ${ }^{2}$ Institut Pasteur d'Alger, Unité d'Entomologie Médicale, Service d’Eco-épidémiologie parasitaire et génétique des populations, Alger, Algérie. ${ }^{3}$ Laboratoire de Biologie Animale Appliquée, Faculté des Sciences, Département de Biologie, Université Badji Mokhtar, Annaba, Algérie. ${ }^{4}$ Unit of Functional and Evolutionary Entomology, Gembloux Agro-Bio Tech, University of Liège, Passage des Déportés 2, 5030 Gembloux, Belgium. ${ }^{5}$ Institut Pasteur, Department of Virology, Arboviruses and Insect Vectors, Paris, France.

Received: 5 February 2016 Accepted: 25 July 2016

Published online: 17 August 2016

\section{References}

1. Vinogradova EB. Culex pipiens pipiens mosquitoes: taxonomy, distribution, ecology, physiology, genetics, applied importance and control. Pensoft: Sofia; 2000.

2. Meegan JM, Khalil GM, Hoogstraal H, Adham FK. Experimental transmission and field isolation studies implicating Culex pipiens as a vector of Rift Valley fever virus in Egypt. Am J Trop Med Hyg. 1980;29(6):1405-10.

3. Moutailler S, Krida G, Schaffner F, Vazeille M, Failloux AB. Potential vectors of Rift Valley fever virus in the Mediterranean region. Vector Borne Zoonotic Dis. 2008;8:749-53. http://doi.org/doi:10.1089/vbz.2008.0009.

4. Krida G, Diancourt L, Bouattour A, Rhim A, Chermiti B, Failloux AB. Assessment of the risk of introduction to Tunisia of the Rift Valley fever virus by the mosquito Culex pipiens. Bull Soc Pathol Exot. 2011;104:250-9.

5. Amraoui F, Krida G, Bouattour A, Rhim A, Daaboub J, Harrat Z, Failloux AB. Culex pipiens, an experimental efficient vector of West Nile and Rift Valley fever viruses in the Maghreb Region. PLoS ONE. 2012 ; 7(5). e36757. http:// doi.org/10.1371/journal.pone.0036757.

6. Senevet G, Andarelli L, Graells R. A propos de Culex pipiens en Algérie. Arch Inst Pasteur Alger. 1958;36:70-4. 
7. Senevet G, Andarelli L, Graells R. Contribution à l'étude de la biologie des moustiques en Algérie et dans le Sahara algérien. Arch Inst Pasteur Alger. 1960;38(2):306-26.

8. Senevet G, Andarelli L. Les moustiques de l'Afrique du Nord et du bassin méditerranéen. Les genres, Culex, Uranotaenia, Theobaldia, Orthopodomyia et Mansonia. Paris : 1959 ; eds. Lechevalier. 384p

9. Amara Korba R, Boukraa S, Alayat MS, Bendjeddou ML, Francis F, Boubidi SC, Bouslama Z. Preliminary report of a mosquito survey at Tonga Lake (NorthEast Algeria). Adv Environ Biol. 2015;9(27):288-94.

10. Pilo-Moron E, Vincent J, Le Corroler Y. Isolation of a West-Nile virus in the extreme south of the Algerian Sahara (Djanet). Arch Inst Pasteur Alger. 1970;48:181-4.

11. Le Guenno B, Bougermouh A, Azzam T, Bouakaz R. West Nile: a deadly virus? Lancet. 1996;9; 348(9037):1315.

12. Triki H, Murri S, Le Guenno B, Bahri O, Hili K, et al. West Nile vira meningo-encephalitis in Tunisia. Med Trop. 2001;61(6):487-90.

13. El Harrack M, Le Guenno B, Gounon P. Isolement du Virus West Nile au Maroc. Virologie. 1997;1(3):248-9.

14. Schuffenecker I, Peyrefitte CN, El Harrak M, Murri S, Leblond A, et al. West Nile virus in Morocco, 2003. Emerg Infect Dis. 2005;11(2):306-9. http://doi. org/10.3201/eid1102.040817.

15. Garbouj M, Bejaoui M, Aloui H, Ben Ghorbal M. La maladie du Nil occidental. Bulletin Epidemiologique. 2003:3:4-6.

16. Ben Hassine T, Conte A, Calistri P, Candeloro L, Ippoliti C, De Massis F, et al. Identification of suitable areas for West Nile virus circulation in Tunisia. Transbound Emerg Dis. 2015;(5)29. http://doi.org/10.1111/tbed.12384.

17. Digoutte JP, Peters CJ. General aspects of the 1987 Rift Valley fever epidemic in Mauritania. Res Virol. 1989;140:27-30. http://doi.org/10.1016/ S0923-2516(89)80081-0.

18. Arsevska E, Hellal J, Mejri S, Hammami S, Marianneau P, Calavas D, Hénaux $V$. Identifying areas suitable for the occurrence of Rift Valley fever in North Africa: Implications for surveillance. Transbound Emerg Dis. 2015; 2(6). http://doi.org/10.1111/tbed.12331.

19. Huang S, Molaei G, Andreadis TG. Genetic insights into the population structure of Culex pipiens (Diptera: Culicidae) in the Northeastern United States by using microsatellite analysis. Am J Trop Med Hyg. 2008;79(4):518-27.

20. Becker N, Jost A, Weitzel T. The Culex pipiens complex in Europe. J Am Mosq Control Assoc. 2012;28:53-67. http://doi.org/10.2987/8756-971X-28.4s.53.

21. Fonseca DM, Keyghobadi N, Malcolm CA, Mehmet C, Schaffner F, et al. Emerging vectors in the Culex pipiens complex. Science. 2004;303:1535-8. http://doi.org/10.1126/science.1094247.

22. Gomes B, Sousa CA, Vicente JL, Pinho L, Calderón I, Arez E, ... Pinto J. Feeding patterns of molestus and pipiens forms of Culex pipiens (Diptera: Culicidae) in a region of high hybridization. Parasit Vectors. 2013; 6, 93. http://doi.org/10.1186/1756-3305-6-93

23. Emberger $\mathrm{L}$. Une classification biogéographique des climats (A biogeographic classification of climates). Recueil Trav Lab Bot Géol Zool Fac Sci Univ Montpellier, Serie Bontanique. 1955;7:3-43.

24. Silver JB. Mosquito Ecology - Field Sampling Methods: Springer. 2008. 1494p.

25. Bahnck CM, Fonseca DM. Rapid assay to identify the two genetic forms of Culex (Culex) pipiens L. (Diptera: Culicidae) and hybrid populations. Am J Trop Med Hyg. 2006;75(2):251-5.

26. Nelms BM, Kothera L, Thiemann T, Macedo PA, Savage HM, Reisen WK Phenotypic variation among Culex pipiens complex (Diptera: Culicidae) populations from the Sacramento Valley, California: horizontal and vertical transmission of West Nile virus, diapause potential, autogeny, and host selection. Am J Trop Med Hyg. 2013;89:1168-78. http://doi.org/10.4269/ajtmh.13-0219.

27. Medlock JM, Snow KR, Leach S. Potential transmission of West Nile virus in the British Isles: an ecological review of candidate mosquito bridge vectors. Med Vet Entomol. 2005;19:2-21. http://doi.org/10.1111/j.0269283X.2005.00547.x.

28. Alto BW, Muturi EJ, Lampman RL. Effects of nutrition and density in Culex pipiens. Med Vet Entomol. 2012;26:396-406. http://doi.org/10.1111/j.13652915.2012.01010.x

29. Kamura T. Studies on the Culex pipiens group of Japan. 4. Ecological studies on the Nagasaki molestus. Endemic Dis Bull Nagasaki Univ. 1959;1(1):51-9.

30. Shute PG. Culex molestus. Trans R Entomol Soc Lond. 1951;102:380-2.

31. Knight KL, Abdel-Malek AA. A morphological and biological study of Culex pipiens in the Cairo area of Egypt. Bull Soc Fouad I Entomol. 1951;35:175-85.

32. Spielman A. Population structure in the Culex pipiens complex of mosquitoes. Bull WHO. 1967;37(2):271-6.
33. Kassim NFA, Webb CE, Russell RC. Culex molestus Forskal (Diptera: Culicidae) in Australia: colonisation, stenogamy, autogeny, oviposition and larval development. Austral Entomol. 2012;51(1):67-77.

34. Pasteur N, Rioux JA, Guilvard E, Pech-Perieres J. A new report of naturally anautogenous and stenogamic populations of Culex pipiens pipiens $L$. in the south of France. Ann Parasitol Hum Comp. 1977;52(2):205-10.

35. Urbanelli S, Villani F, Bullini L. Electrophoretic studies on Culex pipiens quinquefasciatus Say from Africa: genetic variability and divergence from Culex pipeins pipiens L. (Diptera: Culicidae). Bull Entomol Res. 1985;75:291-304.

36. Ishii T. On the Culex pipiens group in Japan. Part III. A historical review of its research 7. Review of larval characters (3). J Sci Tokushima Univ. 1983;16:27-I09.

37. Vinogradova EB. Morphology, ecology and control of the Culex pipiens complex in USSR. Akaieka Newsletter. 1992;15:1-10.

38. Kothera L, Godsey M, Mutebi JP, Savage HM. A comparison of aboveground and belowground populations of Culex pipiens (Diptera: Culicidae) mosquitoes in Chicago, Illinois, and New York City, New York, using microsatellites. J Med Entomol. 2010;47(5):805-13. http://dx.doi.org/10.1093/ jmedent/47.5.805

39. Christophers SR. Structure of the Culex egg and egg-raft in relation to function (Diptera). Trans Roy Entomol Soc Lond. 1945;95(2):25-34. http://doi.org/10.1111/j.1365-2311.1945.tb00260.x.

40. Tate $P$, Vincent $M$. The biology of autogenous and anautogenous races of Culex pipiens. Parasitology. 1936;28(1):115-45.

41. Christophers SR. Note on morphological characters differentiating Culex pipiens $\mathrm{L}$. from Culex molestus Forskal and the status of these forms. Trans R Ent Soc Lond. 1951;102(7):372-9. http://doi.org/10.1111/j.1365-2311.1951.tb00757.x.

42. Lounibos LP, Conn JE. Fecundity, parity, and adult feeding relationships among Nyssorhynchus malaria vectors from Venezuela. Memórias do Instituto Oswaldo Cruz. Rio de Janeiro. 1991;86(1):57-66.

43. Mitchell JC, Briegel $\mathrm{H}$. Fate of blood-meal in force-fed, diapausing Culex pipiens (Diptera: Culicidae). J Med Entomol. 1989;26(4):332-41.

44. Foster WA, Eischen FA. Frequency of blood feeding in relation to sugar availability in Aedes aegypti and Anopheles quadrimaculatus (Diptera: Culicidae). Ann Entomol Soc Ama. 1987:80(2):103-8.

45. Steinwascher K. Egg size variation in Aedes aegypti: relationship to body size and other variables. Am Mid Nat. 1984;112:76.

46. Chevillon C, Eritja R, Pasteur N, Raymond M. Commensalism, adaptation and gene flow: mosquitoes of the Culex pipiens complex in different habitats. Genet Res. 1995;66:147-57.

47. Gomes B, Sousa CA, Novo MT, Freitas FB, Alves R, et al. Asymmetric introgression between sympatric molestus and pipiens forms of Culex pipiens (Diptera: Culicidae) in the Comporta region, Portugal. BMC Evol Biol. 2009;9: 262. http://doi.org/10.1186/1471-2148-9-262.

48. Reusken CB, de Vries A, Buijs J, Braks MA, den Hartog W, et al. First evidence for presence of Culex pipiens biotype molestus in the Netherlands, and of hybrid biotype pipiens and molestus in northern Europe. J Vector Ecol. 2010; 35:210-2. http://doi.org/10.1111/j.1948-7134.2010.00050.x

49. Gomes B, Kioulos E, Papa A, Almeida AP, Vontas J, Pinto J. Distribution and hybridization of Culex pipiens forms in Greece during the West Nile virus outbreak of 2010. Infect Genet Evol. 2013;16:218-25. http://doi.org/10.1016/j. meegid.2013.02.006.

50. Amraoui F, Tijane M, Sarih M, Failloux AB. Molecular evidence of Culex pipiens form molestus and hybrids pipiens/molestus in Morocco. North Africa Parasit Vectors. 2012;5:83. http://doi.org/10.1186/1756-3305-5-83.

51. Krida G, Rhim A, Daaboub J, Failloux AB, Bouattour A. New evidence for the potential role of Culex pipiens mosquitoes in the transmission cycle of West Nile virus in Tunisia. Med Vet Entomol. 2015;29(2):124-8. http://doi.org/10.1111/mve.12107.

52. Hamer GL, Kitron UD, Brawn JD, Loss SR, Ruiz MO, et al. Culex pipiens (Diptera: Culicidae): a bridge vector of West Nile virus to humans. J Med Entomol. 2008:45(1):125-8.

53. Rudolf M, Czajka C, Börstler J, Melaun C, Jöst H, von Thien H, et al. First nationwide surveillance of Culex pipiens complex and Culex torrentium mosquitoes demonstrated the presence of Culex pipiens biotype pipiens/ molestus hybrids in Germany. PLoS ONE, 8(9), e71832. http://doi.org/10. 1371/journal.pone.0071832.

54. Spielman A. Structure and seasonality of nearctic Culex pipiens populations. Ann NY Acad Sci. 2001:951:220-34.

55. Tahori AS, Sterk W, Goldblum N. Studies on the dynamics of experimental transmission of West Nile virus by Culex molestus. Am J Trop Med Hyg. 1955;4:1015-27. 
56. Turell MJ, Dohm DJ, Sardelis MR, O'Guinn ML, Andreadis TG, Blow JA. An update on the potential of north american mosquitoes (Diptera: Culicidae) to transmit West Nile virus. J Med Entomol. 2005;42(1):57-62.

57. Menzel S, Bouchnak R, Menzel R, Steinberg CE. Dissolved humic substances initiate DNA-methylation in cladocerans. Aquat Toxicol. 2011;105(3):640-2.

58. Navarro-Martín L, Viñas J., Ribas L., Díaz N, Gutiérrez A, Di Croce L, \& Piferrer F. DNA methylation of the gonadal aromatase (cyp19a) promoter is involved in temperature-dependent sex ratio shifts in the European sea bass. PLoS Genet. 2011; 7(12). e1002447. http://doi.org/10.1371/journal.pgen.1002447.

59. Kille PJ, Andre C, Anderson HN, Ang MW, Bruford JG, Bundy R, et al. DNA sequence variation and methylation in an arsenic tolerant earth worm population. Soil Biol Biochem. 2013;57:524-32.

60. Fraga MF, Ballestar E, Paz MF, Ropero S, Setien F, Ballestar ML, et al. Epigenetic differences arise during the lifetime of monozygotic twins. PNAS 2005;102(30): 10604-10609. http://doi.org/10.1073/pnas.0500398102

61. Finnegan EJ, Dennis ES. Vernalization-induced trimethylation of histone $\mathrm{H} 3$ lysine 27 at FLC is not maintained in mitotically quiescent cells. Current Biol. 2007;17(22):1978-83

62. Schmitz RJ, Sung S, Amasino RM. Histone arginine methylation is required for vernalization-induced epigenetic silencing of FLC in winter-annual Arabidopsis thaliana. PNAS. 2008;105(2):411-6. http://doi.org/10.1073/pnas. 0710423104

\section{Submit your next manuscript to BioMed Central} and we will help you at every step:

- We accept pre-submission inquiries

- Our selector tool helps you to find the most relevant journal

- We provide round the clock customer support

- Convenient online submission

- Thorough peer review

- Inclusion in PubMed and all major indexing services

- Maximum visibility for your research

Submit your manuscript at www.biomedcentral.com/submit 